\title{
'The biggest car crash in NHS history': the media portrayal of GP pay before and after the introduction of the Health and Social Care Bill 2011
}

\author{
Adam Balkham ${ }^{1}$ and Sarah Alderson ${ }^{2}$ \\ ${ }^{1}$ Medical Student, Leeds Institute of Health Sciences, Charles Thackrah Building, University of Leeds, Leeds, UK \\ ${ }^{2}$ Clinical Lecturer in Primary Care, Leeds Institute of Health Sciences, Charles Thackrah Building, University of Leeds, Leeds, UK
}

\begin{abstract}
Background: The introduction of the Health and Social Care Bill (2011) changed the role of GPs to include commissioning of health services. Aim: This study aimed to identify any differences in the media portrayal of GPs before and after the introduction of the Bill. Methods: We retrospectively searched four British newspapers over the period 2009-2013 using the media database Nexis. In order to directly compare the findings of the study with the work of Tanner et al., articles relating to GP pay were analysed using thematic analysis. Themes were identified and each article was scored to determine whether it portrayed GPs positively or negatively. Results: GPs were portrayed slightly less negatively after the introduction of the Bill. The theme of 'high salaries' persisted despite reference to 'pay freezes'. References to decreased trust in the patient-doctor relationship appeared after the introduction of the Bill. Conclusion: Negative portrayal of GP pay has continued and a lack of trust in GPs has started to be portrayed. This trend may exacerbate the low morale amongst the profession and difficulties in recruiting and retaining GPs.
\end{abstract}

Key words: General practitioner; GP; GP pay; media portrayal; Health and Social Care Bill

Received 24 September 2015; revised 25 July 2016; accepted 27 August 2016;

first published online 17 October 2016

\section{How this fits in}

Healthcare in England has recently undergone some of the biggest changes since the introduction of the National Health Service (NHS) in 1948. However, with focus on the reforms and their consequences, little has been published on how the media has portrayed general practitioners during this period.

\section{Introduction}

The Health and Social Care Bill (2011) was introduced by the then Health Secretary, Andrew

Correspondence to: Adam Balkham (and Sarah Alderson), Leeds Institute of Health Sciences, Charles Thackrah Building, University of Leeds, Leeds, LS2 9LJ, UK. Email: adam. balkham@gmail.com
Lansley. The Bill led to the abolishment of Primary Care Trusts (PCTs), who were previously responsible for commissioning primary, community and secondary health services from health providers and their role was replaced by the introduction of Clinical Commissioning Groups (CCGs) (Ham, 2012). In 2001, 303 PCTs were created, each serving a population of just fewer than 200000 . PCTs were monitored by regional Strategic Health Authorities (SHAs) and nationally, by the Department of Health. PCTs were ultimately responsible for $80 \%$ of the NHS budget (Department of Health, 2001). By contrast, CCGs are clinically led GP groups that replaced the administrative managers of PCTs with the aim to give GPs the control of commissioning healthcare services. Overall, the Bill sought to drastically change the structure of the NHS by increasing

\footnotetext{
(C) Cambridge University Press 2016
} 
GP responsibility with devolution from central government. There are now 209 CCGs in England responsible for $60 \%$ of the NHS budget. There is also now a single regulatory body, NHS England, compared with more regional SHAs. The body was formed to oversee the running of CCGs and to commission healthcare when a CCG is unable to do so (NHS Clinical Commissioners, 2015).

The Health and Social Care Bill was widely considered a political 'car crash' (Porter, 2011, n.p.). Concerns about the sheer scale of the reforms were widespread and raised by many key organisations, from the Nuffield Trust to the Royal College of Nursing (NHS Confederation, 2011; BMJ News, 2011; BBC News, 2012; Timmins, 2012). Hospital chief executives expressed concern that 'handing over the commissioning of care to GPs is the equivalent of letting the local garage run BP, or the corner shop run Sainsbury's' (Timmins, 2010, n.p.). A study by Tanner et al. (2010) reported that despite GP pay being portrayed by the media as 'unfavourable' as the introduction of the new General Medical Services (GMS) contract in 2004 (Department of Health, 2004), the level of public trust in GPs remained constant. However, it acknowledged that a continued level of negative coverage could tip the balance. With GPs taking on responsibility for commissioning healthcare services, the patient-doctor relationship and public trust in primary care has become more important than ever before. This study aimed to assess the impact of the Health and Social Care Bill on the media portrayal of GPs.

\section{Methods}

Media can be defined as 'The main means of mass communication, esp. newspapers, radio, and television, regarded collectively; the reporters, journalists, etc.' (Oxford English Dictionary, 2014a, n.p.). In order to extend the study by Tanner et al. (2010) and to compare and review current trends, only written media was explored. Journalism is a very powerful way of communicating and providing information and in context, can shape a person's opinion of GPs. Newspapers specifically are very useful as they provide information on current events and trends at the time of publication (Richardson, 2007). To obtain a fair
Box 1 National readership of popular newspapers October 2012-11 September 2013
1. The Sun $(5685000)$
2. Daily Mail (4074000)
3. Daily Mirror (2975000)
4. The Daily Telegraph (1313000)
5. The Times $(1155000)$
6. The Guardian (793000)
7. The Independent (309000)

representation of newspaper sources, a balance of tabloids and broadsheets was used.

We searched and analysed articles published in four newspapers between 19 January 2009 and 19 January 2013: The Sun, Daily Mail, The Daily Telegraph and The Guardian. Newspapers were selected according to readership (Box 1), political stance and format (broadsheet or tabloid). The Sun and Daily Mail were chosen as the UK's most popular newspapers, respectively (NRS, 2013) and The Daily Telegraph as the most popular broadsheet. Although The Guardian is a less popular broadsheet, it was selected over The Times to maintain some political balance as The Times is also owned by the same company as The Sun (News Corp UK, 2014). Despite different target audiences, the core principles of the two papers might be very similar. As the Daily Mirror is less popular than the Daily Mail and The Sun, it was discounted to include an equal number of tabloids and broadsheets. We used the database Nexis (LexisNexis, 2014) to search for relevant articles. Ethical review was not required.

Since the introduction of the 2004 GMS contract (Department of Health, 2004), the financing and pay of health and other public sector workers continues to be a 'hot topic' (Neville and Pickard, 2014). In order to directly compare the findings of the study with the work of Tanner et al. (2010), the research adopted a more deductive approach with a preconceived framework of GP pay. Initial screening of articles was undertaken by one reviewer (A.B.). A number of trial searches were carried out using specific Boolean search terms including the established framework of GP pay. Variations of the acronym 'GP' were excluded. 'Non-business news' was unselected to avoid picking up lifestyle and entertainment articles, birth and wedding announcements, obituaries, Primary Health Care Research \& Development 2017; 18: 84-91 
community events, sports, weather, etc. Newswires were included. These are stories that are provided in bulk to newspapers from an external agency. What the newspaper chooses to acquire and publish is still representative of that newspaper even if they are produced by an external agency. Further publications, for example editorials, letters and articles that satisfied the correct search criteria were included in the study as a written media portrayal of GPs. The final search was divided into time frames before (19 January 2009-19 January 2011) and after (20 January 2011-19 January 2013) the introduction of the Bill (Appendix).

We used thematic analysis to identify and code themes that emerged from the articles (Braun and Clark, 2006). Text was highlighted and key quotes recorded in order to identify emerging codes before and after the Bill by one author (A.B.). Both authors (A.B. and S.A.) discussed the coding process and the development of themes throughout the analysis process. The study focussed on the framework of pay, but thematic analysis facilitated the exploration of further themes. The study progressed by making inferences from the general to the particular (Braun and Clark, 2006; Guest et al., 2012). We applied a scoring system to the data to analyse any trend in reporting. Articles were assigned a score of $+1,-1$ or 0 depending whether the overall portrayal of GPs was positive, negative or neutral, respectively, within each article. These scores were then totalled to give the overall positive/negative depiction of GPs before and after the introduction of the Health and Social Care Bill. As there were twice as many articles post-Bill, the percentages of positive, negative and neutral articles for each period were then calculated. Percentages were also calculated to determine the frequency of specific themes before and after the Bill. The top five themes for each period were discussed and agreed by consensus (A.B. and S.A.) before being recorded and compared.

\section{Results}

A total of 42 articles were identified before the Bill and 84 articles identified after the Bill. GPs were portrayed negatively both before and after the introduction of the Bill, although the score after the Bill was less negative (Table 1).

Primary Health Care Research \& Development 2017; 18: 84-91
Table 1 Identified articles before and after the introduction of the Bill

\begin{tabular}{lcc}
\hline & Pre-bill (\%) & Post-bill (\%) \\
\hline Positive articles & 0 & 6 \\
Negative articles & 59.5 & 43 \\
Neutral articles & 40.5 & 51 \\
Total score & -59.5 & -49 \\
\hline
\end{tabular}

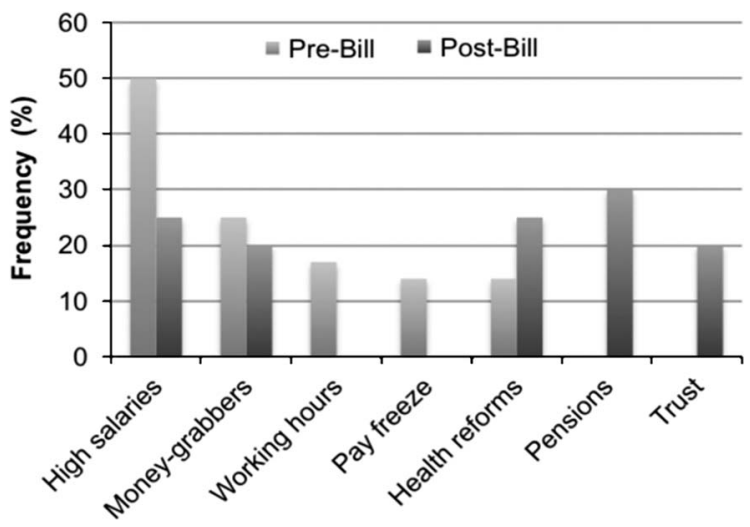

Figure 1 Percentage frequency of identified themes for the periods before and after the Bill

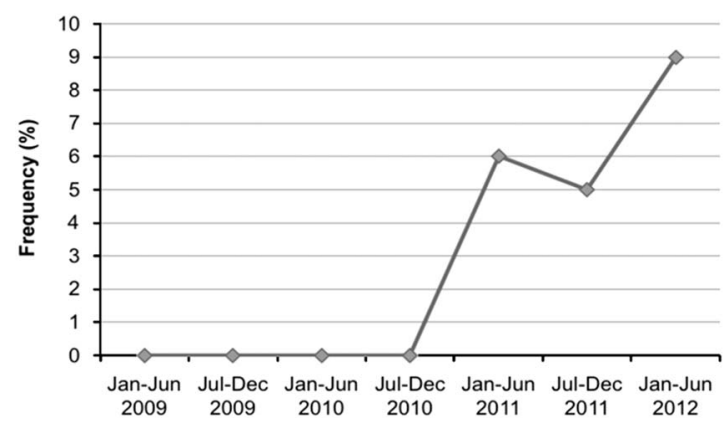

Figure 2 Percentage frequency of 'trust' being reported in media articles before and after the Bill

The top five themes were selected for each of the periods before and after the introduction of the Bill (Figure 1). Trust in GPs appeared for the first time as a theme after the introduction of the Bill (Figure 2). Themes related to high salaries and money-grabbing by GPs were present after the introduction of the Bill, but not as frequently. 


\section{Key quotations}

\section{High salaries}

'More than 4000 GPs are now earning more than the Prime Minister ...'.

'Family doctors' pay has soared since the introduction of a "bungled" new contract in 2004 ...'.

(Borland, S. 4000 GPs earning more than the PM, Daily Mail, 29 September 2010)

'I can go to all the parties and weddings I like'.

(Andrews, H. Weekend: Because you're worth it: GP Helen Andrews, 30, £51000. The Guardian, 20 November 2010)

'Family doctors are in line for further big pay rises ...'.

(Another nice little earner for the GPs. Daily Mail, 20 January 2011)

\section{Money-grabbers}

'... family doctors ... use the 084 numbers to raise cash, with patients paying $£ 1$ to fix an appointment ...'.

(Wooding, D. GP calls joy. The Sun, 14 September 2009)

'... GPs ... clearly it is wrong if they also charge for blood testing ...'.

(Flynn, P. GPs bleeding patients dry. The Sun, 9 February 2011)

'Dishonest GPs are defrauding the taxpayer of millions of pounds by claiming money for "ghost patients".

(Sears, N., Harding, E., and Borland, S. Phantom patients net GPs millions.

Daily Mail, 10 September 2011)

\section{Working hours}

'GP pay has soared by more than 50 per cent ... more money for working fewer hours'.

(Hope, J. Patient complaints cost GPs millions. Daily Mail, 30 June 2009)

\section{Pay freeze}

'While there has been an overall decrease in GPs' earnings, we must ensure better value for money ...'.

(Collins, N. The 1000 GPs on $£ 200000$ a year.

The Daily Telegraph, 16 September 2010)

'... family doctors will not be paid any extra for taking on the considerable extra responsibilities involved in commissioning ...'.

(Campbell, D. GPs power, but no more pay. The Guardian, 10 July 2010)

\section{Pensions}

'... GPS ... their gold-plated NHS pension scheme ...'.

(Martin D. We'll quit early to beat pension threat says GPs. Daily Mail, 23 March 2011)

'Trainee GP sees uncertain future ... please someone listen before we run out of GPs'.

(Reforms 'risk NHS running out of GPs'. The Daily Telegraph, 23 May 2012)

'The strike shows that the BMA puts cash before care'.

(Poulter D. and Buckman L. Doctors' strike debate: Is the BMA putting cash before care?

The Daily Telegraph, 21 June 2012)

\section{Health reforms}

'A new contract that makes GPs more accountable ...'.

(Porter, A. Biggest revolution in NHS for 60 years; billions to be handed to GPs as health authorities are axed GPs get crucial role in reform. The Daily Telegraph, 9 July 2010)

'... put GPs in control of $£ 80$ billion ...'.

(GPs eye pay hike. The Sun, 10 July 2010)

'... the new family doctor will become part accountant, ...'.

(Ramesh, R. The future of the NHS: the promarket family doctors eager for a dose of

Primary Health Care Research \& Development 2017; 18: 84-91 
Lansley's medicine: GP consortiums competing for patients will break up the health service, critics say. The Guardian, 16 March

'GPs could more than double their income to $£ 300000$ a year ...'.

(Ramesh, R. and Campbell, D. NHS reforms could spawn $£ 300000$-a-year GPs.

The Guardian, 16 March 2011)

'... how on earth can these people find time to manage a complex behemoth such as the NHS?'

(Sykes, M. GPs may be generously paid, but they fund their own pension schemes.

The Telegraph, 13 March 2012)

\section{Trust}

'... to reward GPs for enforcing budgetary controls could fundamentally damage trust with patients'.

(Syal, R. BMA chief warns budget rewards could destroy trust in GPs. The Guardian,

27 June 2011)

'Once you lose the public's trust, it's difficult to get it back'.

(Adams, S. Doctors' pensions: most GPs could work as normal on June 21; More than

half of GPs could go to work as normal on

June 21, according to a poll, indicating possible waning support for taking industrial action over their pensions. The Telegraph,

12 June 2012)

'... that trusting relationship is undone... serious consequences for patient care'.

(Ramesh, R. and Campbell D. NHS reforms could spawn $£ 300000$-a-year GPs.

The Guardian 16 March 2011)

\section{Discussion}

After the introduction of the Bill, there were fewer negative and more positive press articles about GPs compared with the period before the introduction. Despite the marginally improved results, the overall score remained negative. Key themes of high salaries, money-grabbing GPs and health reforms occurred both before and after the Bill. Mentions of working hours and pay freeze disappeared after the Bill and new themes relating to pensions and trust appeared after the Bill.

The most frequently reported theme was high salaries, which was possibly a ripple effect of the 2004 GMS contract. This contract aimed to improve GP morale and increase recruitment as well as improve the quality of patient care. Its introduction led to widespread concerns about lack of access to out-of-hours primary care and GP pay (Tanner et al., 2010). We found the majority of articles looking at GP pay focussed on extremes such as the 'The $£ 1 / 2$ M GP' (Phillips, 2010: 2) or ‘ $£ 300000$ a year GPs’ (Sears, 2010, n.p.), rather than average pay. According to current information, the average salary of a GP partner is $£ 105300$ (BMA, 2014) and between £54863 and $£ 82789$ for a salaried GP (NHS Careers, 2014). With the well-documented public sector 'pay-freeze' (NHS Confederation, 2013; Neville and Pickard, 2014) and the need to 'continue with public sector pay restraint in order to put the nation's finances back on a sustainable footing' (HM Treasury, 2014, n.p.), it can be expected that references to GP 'high salaries' in the media will continue to decline.

Importantly, the concerns posed by Tanner et al. (2010) that patient-doctor trust might be negatively affected in the future by negative portrayal of GPs in the media are now an issue. The findings of this study show that following the introduction of the Bill, negative articles relating to patient-doctor 'trust' started to appear (Figure 2). The introduction of the Bill and placement of GPs at the forefront of the health service means that trust in family doctors is more important than ever. A combination of an increase in patient expectation (Royal College of General Practitioners, 2007), prolonged media interrogation of GPs (Tanner et al., 2010), continued scrutiny of public sector pay (Neville and Pickard, 2014), and scandals related to the NHS have brought into question the integrity of the medical profession and GPs (Delamothe, 2010).

The main strength of the study was the range of most popular newspapers selected and reviewed. Popular national newspapers are written to appeal 
to the wide public audience and can have a large impact on public opinion. The study covered $53 \%$ of the combined national daily readership (NRS, 2013).

The study has four main limitations. First, most of the papers that were chosen are more right leaning politically and a more balanced selection of papers could have been chosen. Second, newspaper reporting is subject to sensationalisation and newspapers are written to have impact, with facts often exaggerated and negative news being more commonly represented (Nelkin, 1996; Johnson, 1998). Third, the use of thematic analysis has the disadvantage of its disregard of more 'nuanced' data and writing styles (Guest et al., 2012). Therefore, the way in which topics were reported was not reviewed. For example, newspaper journalists may have embellished a single GP's misdemeanour for effect. A GP practice in York was reported as offering patients services not available on the NHS for a private fee (Beckford, 2011). By initially introducing the topic as 'doctors' implied that such a finding was the norm. Fourth, a more specific approach focussing on pay may have resulted in a negative bias by narrowing the search too much.

The continuing negative depiction of GPs could have potentially detrimental consequences. At a patient level, decreased trust in doctors may lead to the questioning of a doctor's integrity and this could seriously hamper a collaborative relationship (Levenstein et al., 1989; Wanless, 2002). A partnering relationship is fundamental in the continuity of care. From a doctor's perspective, it was reported that 'half of GPs want out ... with many blaming NHS reforms' (The Sun, 2011: 2). Not only did a number of doctors consider retirement after the Bill, but also more worryingly, there was a fear that fewer medical graduates would want to become GPs with morale being at an all-time low (Rimmer, 2014). Continuous negative portrayal of GPs is likely to contribute to the problem with recruiting and retaining GPs (Royal College of General Practitioners, 2015).

Many professions have been subjected to media criticism in recent times. To name but a few: bankers, teachers, academics, social workers and members of parliament (MPs). The difference between GPs and these other professions is the stark contrast following the introduction of the 2004 GMS contract. GPs were well regarded pre-2004 (Tanner et al., 2010). They were considered hardworking and loyal before being portrayed as money-grabbers by the media following the new contract. This negative portrayal has persisted and deteriorated into a trend relating to patient-doctor trust coinciding with the 'biggest car crash in NHS history' (Porter, 2011, n.p.). Further progression may significantly hamper public trust in GPs, with morale continuing to be the lowest of all medical specialties.

\section{Acknowledgements}

The research was completed as part of the Primary Care BSc intercalation course at the University of Leeds. It is an extension of the previous published work by Tanner et al. entitled 'Wads up, doc' trends in British newspapers', which reported on general practitioners' pay. We thank the Primary Care course leads Kristan Toft and Catie Nagel for their support.

\section{References}

BBC News. 2012: Health Reforms - where they stand. Retrieved 23 February 2014 from http://www.bbc.co.uk/ news.

Beckford, M. 2011: Pay us and we'll give you the treatment the NHS won't, doctors tell patients; GP services 'will create conflicts of interest'. The Daily Telegraph, p. 1.

BMA 2014: Focus on taking on new partners - guidance for GPs [Online]. Retrieved 23 May 2014 from http://bma.org.uk/ practical-support-at-work/gp-practices/focus-on-taking-onnew-partners

BMJ News. 2011: Reaction: what they say about the health Bill. BMJ. 342(413). Retrieved 23 February 2014 from http://www.bmj.com/content/342/bmj.d413.

Braun, V. and Clarke, V. 2006: Using thematic analysis in psychology. Qualitative Research in Psychology 3, 77-101.

Delamothe, T. 2010: Repeat after me: 'Mid Staffordshire'. BMJ 340, 132.

Department of Health. 2001: Shifting the balance of power within the NHS - securing delivery. London: Department of Health. Retrieved 15 August 2015 from http://www. nhshistory.net/shiftingthebalance.pdf.

Department of Health. 2004: The National Health Service (General Medical Services Contracts) Regulations 2004. London: Department of Health. Retrieved 5 June from http://www.legislation.gov.uk/uksi/2004/291/pdfs/uksi_20040 291_en.pdf.

Guest, G., MacQueen, K. and Namey, E. 2012: Applied thematic analysis. Los Angeles, CA: Sage publications.

Primary Health Care Research \& Development 2017; 18: 84-91 
Ham, C. 2012: What will the Health and Social Care Bill mean for the NHS in England? BMJ 344, 2159.

Health and Social Care Bill. 2011: HL Bill 92. London: The Stationery Office.

HM Treasury. 2014: Public sector pay awards for 2014-15. Retrieved 6 June 2014 from https://www.gov.uk/government/ news/public-sector-pay-awards-for-2014-15.

Johnson, T. 1998: Shattuck lecture - medicine and the media. The New England Journal of Medicine 339, 87-92.

Levenstein, J., Brown, J., Weston, W., Stewart, M., McCracken, E. and McWhinney, I. 1989: Patient-centred clinical interviewing. In Stewart M. and Roter D., editors Communicating with medical patients. Newbury Park, CA: Sage Publications.

LexisNexis. 2014: LexisNexis Academic. Retrieved 8 June 2014 from http://www.lexisnexis.com/en-us/products/lexisnexisacademic.page.

Nelkin, D. 1996: An uneasy relationship: the tensions between medicine and the media. The Lancet 347, 1600-603.

Neville, S. and Pickard, J. 2014: Unions slams public sector 1\% pay rise. Financial Times. 13 March. Retrieved 5 June 2014 from http://www.ft.com/cms/s/0/3fdc8306-aa9d-11e3-9fd600144feab7de.html\#axzz33n98L68k.

News Corp UK. 2014: News UK. Retrieved 18 May 2014 from http://news.co.uk/.

NHS Careers. 2014: Pay for doctors. Retrieved 23 May 2014 from http://www.nhscareers.nhs.uk/explore-by-career/doctors/ pay-for-doctors/.

NHS Clinical Commissioners. 2015: About CCGs. Retrieved 15 August 2015 from http://www.nhscc.org/ccgs/.

NHS Confederation. 2011: Where next for NHS reform?. London: The NHS Confederation. Retrieved 19 May 2014 from http://www.nhsconfed.org/Publications/Documents/ NHS_reform_discussion_paper_0411.pdf.

NRS. 2013: Readership estimates - newspaper and supplements. Retrieved 18 May 2014 from http://www.nrs.co.uk/ downloads/feb-top-liners/newspapers_201312.pdf.

Oxford English Dictionary. 2014: s.v. media. Retrieved 6 June 2014 from www.oed.com.

Phillips, R. 2010: The $£ 1 / 2$ M GP. The Sun. 6 September, 2.

Porter, A. 2011: David Cameron's NHS reforms are now a 'car crash', says Alan Milburn. The Telegraph. 15 June.
Retrieved 27 May 2014 from http://www.telegraph.co.uk/ news/politics/8578022/David-Camerons-NHS-reforms-are-nowa-car-crash-says-Alan-Milburn.html.

Richardson, JE. 2007: Analysing newspapers. Basingstoke: Palgrave Macmillan.

Rimmer, A. 2014: GPs have lowest morale of any specialty, BMA survey finds. Retrieved 15 July 2015 from http://careers. bmj.com/careers/advice/view-article.html?id=20018363.

Royal College of General Practitioners. 2007: The Future Direction of General Practice: A Roadmap. London: Royal College of General Practitioners. Retrieved 24 May 2014 from http://www.rcgp.org.uk/policy/rcgp-policy-areas/ /media/ Files/Policy/A-Z-policy/the_future_direction_rcgp_road map.ashx.

Royal College of General Practitioners. 2015: RCGP launches first-ever recruitment video to attract more GPs into frontline patient care. Retrieved 15 August 2015 from http://www.rcgp.org.uk/news/2015/january/rcgplaunches-first-ever-recruitment-video-to-attract-more-gpsinto-frontline-patient-care.aspx.

Sears, N. 2010: NHS deal means $£ 300,000$-a-year GPs have chance to top up privately. Daily Mail. [Online]. Retrieved 16 September 2016 from http://www.dailymail.co.uk/news/ article-1257875/GPs-enjoy-salaries-300-000-insist-deserveit.html

Tanner, F., Foy, R. and Harrison, W. 2010: 'Wads up, doc' trends in British newspapers' reporting of general practitioners' pay. Primary Health Care Research \& Development 11, 405-9.

The Sun. 2011: Half of GPs want out. The Sun. 1 September, 2. Timmins, N. 2010: Healthcare model set for radical shake-up. Financial Times. 15 August. Retrieved 28 May 2014 from http://www.ft.com/cms/s/0/6e0d14e6-a88c-11df-86dd-00144fea bdc0.html\#axzz32tkdJMRs.

Timmins, N. 2012: Never again? The story of the health and social care act 2012. London: The King's Fund. Retrieved 27 May 2014 from http://www.kingsfund.org.uk/sites/files/kf/ field/field_publication_file/never-again-story-health-socialcare-nicholas-timmins-jul12.pdf.

Wanless, D. 2002: Securing our future health. London: HM treasury. 


\section{Appendix}

Final search for articles.
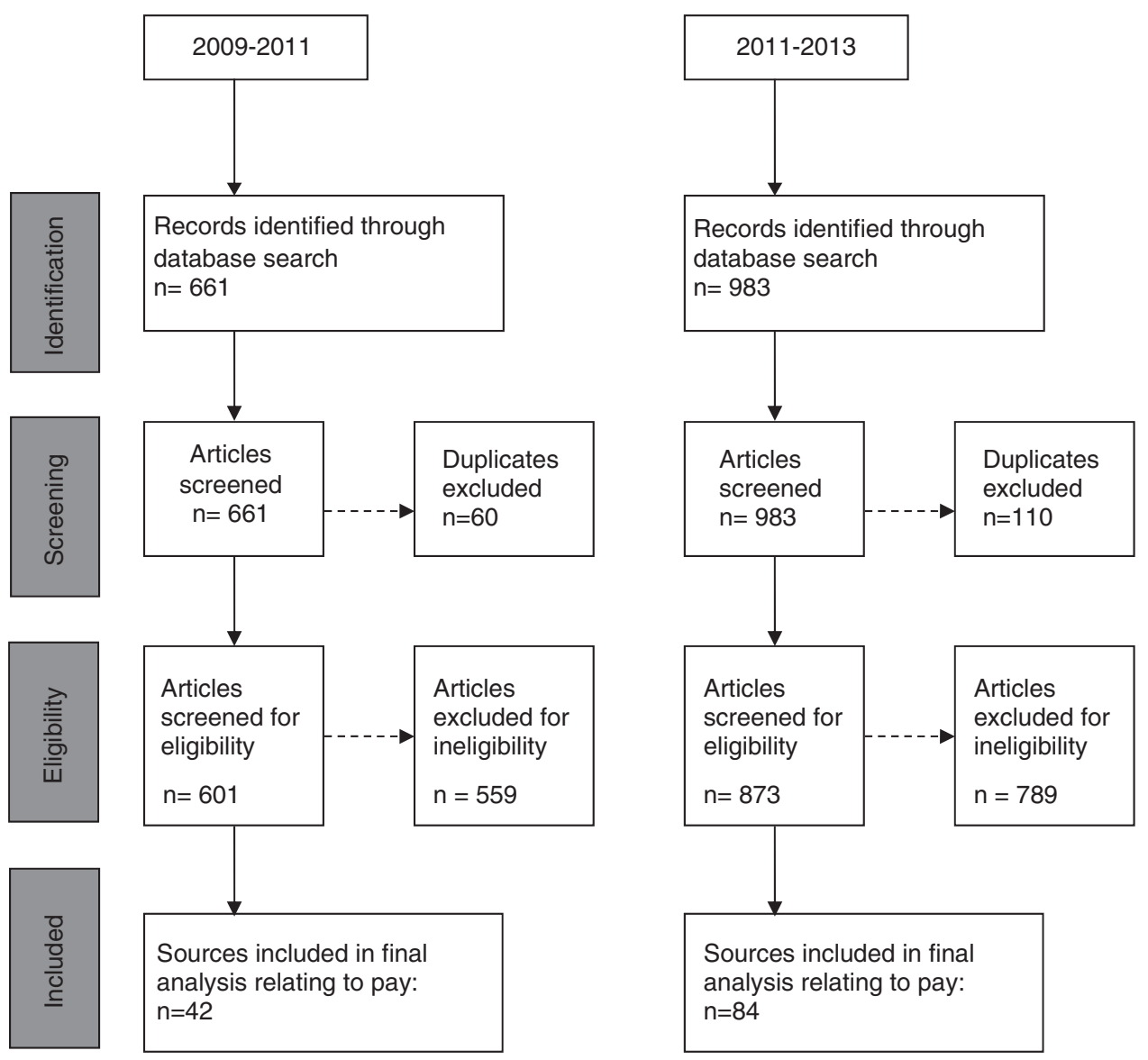